Journal of Community Based Environmental Engineering and Management, 2021, Vol. 5, No. 1: 1-8

\title{
ECONOMIC VALUATION WITH TRAVEL COST METHOD (TCM) SLANIK WATERPARK SOUTH LAMPUNG DISTRICT
}

\author{
Muhammad Teguh Wibowo*, Zainal Abidin, Lina Marlina \\ Agribusiness, University of Lampung
}

\begin{abstract}
This study aims to analyze: (1) the factors that affecting the number of tourist visits, (2) the economic value of the Slanik Waterpark in South Lampung District, (3) the visitor satisfaction with tourism cost attribute. This study uses survey method involving 70 respondents who came during the COVID 19 outbreak. The first objective uses multiple linear regression analysis, the second objective uses consumer surplus analysis, and the third uses the Customer Satisfaction Index (CSI) analysis. Data was collected in June until July 2020. The research shows that the factors that influence the number of tourist visits Slanik Waterpark are travel costs and days of visits, the economic value of the Slanik Waterpark tourist attraction is IDR 13,060,150,376 every year, the visitors are satisfied with the cost attributes incurred when traveled to Slanik Waterpark.
\end{abstract}

Keywords: tourism, economic value, visitor satisfaction

\section{Introduction}

Tourism developement is a scope of a broad developement, starting from society to the whole economic aspects in that society (Dwiatmojo, 2015). Through support and specific concern, tourism development process is focused on the progress tourism aspect in order to enable to run economic sector. According to tourism law about tourism 1990, tourism is support including facility and service provided by the government, entrepreneurs, and community for any kind of tourism activities (Nugroho, 2010).

Lampung province is one of provinces with a large number of tourism potentials. One of regencies in Lampung which has a good tourism potential is South Lampung.

\footnotetext{
${ }^{*}$ Corresponding Author:

E-mail: mteguhw27@gmail.com
}

Received: 11 November 2020

Revised : 6 February 2021

Accepted: 7 February 2021
South Lampung has the biggest waterpark as a tourism place in Lampung which is classified as a new tourism place named Slanik Waterpark. Slanik Waterpark is launched on 6th of February 2016 and it was well welcomed by Lampungnese people. A wide land is managed by the manager in order to provide supporting facilities which make visitors comfortable during their visit.

Slanik Waterpark contributes well to the economic aspect of people and traders nearby. One of the examples is the number of stores increasing around Slanik Waterpark. Now there are two souvenir shops opened, more than three stalls and repair shops. Another contribution can be seen from the good employment, the improvement of access road to Slanik Waterpark in order to enable visitors to visit Slanik Waterpark easily. This thing encourages the manager of Slanik Waterpark to develop the target number of visitors. 
The need of community towards water tourism place motivates the manager to provide attractive water park facilities switch enable to attract the visitors. This is important to increase the number of visitors so that Slanik Waterpark becomes more popular among the community.

\section{Research Methodology}

Factors affecting the number of visitors

Factors affecting the number of visitors can be seen through variable model of travel cost, distance, safety, accessibility, income, facility. Visiting days which are analyzed with multiple linear regression. With the indicator if significance probability $>0,1, \mathrm{H} 0$ is accepted and $\mathrm{H} 1$ rejected. If significance probability < 0,1, H0 rejected and $\mathrm{H} 1$ accepted (Ghozali, 2011).

$$
\begin{aligned}
Y= & a+b_{1} X_{1}+b_{2} X_{2}+b_{3} X_{3}+b_{4} X_{4}+b_{5} X_{5}+ \\
& b_{6} X_{6}+b_{6} D_{1}+b_{7} D_{2}+e
\end{aligned}
$$

Note :

$$
\begin{aligned}
\mathrm{a}= & \text { constant } \\
\mathrm{b}= & \text { regression coefficient } \\
\mathrm{Y}= & \text { The number of visit } \\
\mathrm{X} 1= & \text { Travel cost }(\mathrm{Rp} / \mathrm{Knj}) \\
\mathrm{X} 2= & \text { Distance }(\mathrm{Km}) \\
\mathrm{X} 3= & \text { hygiene }(\text { Very clean/ Clean/ Clean } \\
& \text { enough/ Dirty/Very dirty) } \\
\mathrm{X} 4= & \text { Safety }(\text { Very safe/Safe/Safe enough/ } \\
& \text { Unsafe } / \text { Very unsafe }) \\
\mathrm{X} 5= & \text { Accessibility (Hour/Knj) } \\
\mathrm{X} 6= & \text { Revenue }(\mathrm{Rp} / \text { Month }) \\
\mathrm{D} 1= & \text { Facility } \\
& 1=\text { Good } \\
& 0=\text { Insufficient } \\
\mathrm{D} 2= & \text { Visiting days } \\
& 1=\text { weekdays } \\
& 0=\text { weekend } \\
\text { e. }= & \text { Error }
\end{aligned}
$$

\section{Economic Value}

After that, analyzing economic value travel cost method was by counting consumer surplus value per individual per year, according to Fauzi (2014).
$\mathrm{SK}=\frac{V^{2}}{2 \beta 1}$

Note:

SK = Consumer surplus (Rp/person)

$\mathrm{V}=$ The number of respondents' visit (times/year)

$\beta_{1} \quad=$ Travel cost coefficient (TC)

The formulation of the total economic value is based on Marsinko et al (2002).

$\mathrm{EV}=\mathrm{SK} \times \mathrm{TP}$

Note :

$\mathrm{EV}=$ Economic value of the tourism place area in a year (Rp/year)

SK = Surplus consumer visitor per person/visit (Rp/person)

$\mathrm{TP}=$ The average total of visit per year (person)

Visitors' satisfaction

Visitors' satisfaction was analyzed by using costumer satisfaction index (CSI) with likert scale on transportation cost attribute, consumption cost, entrance ticket cost, gazebo rent cost, swimming tire rent cost, cable car cost, parking fee etc. By seeing the level of importance and visitors reality. Scale and interpretation which are used to see consumers' satisfaction can be seen in the table 1 and 2 .

Table 1. Determination of the level of satisfaction and Customer analysis interpretation Satisfaction Index (CSI) (Supranto, 2006)

\begin{tabular}{cl}
\hline Scale range & \multicolumn{1}{c}{ Interpretation } \\
\hline $0.00-0.21$ & Very unsatisfied \\
$0.21-0.40$ & Unsatisfied \\
$0.41-0.60$ & Quite satisfied \\
$0.61-0.80$ & Satisfied \\
$0.81-100$ & Very satisfied \\
\hline
\end{tabular}


Table 2.The score of the level of importance and the level of reality (Supranto, 2006).

\begin{tabular}{clc}
\hline \multirow{3}{*}{$\begin{array}{c}\text { Score of the level of } \\
\text { importance }\end{array}$} & Answer criteria & Score \\
\cline { 2 - 3 } & Very unimportant & 1 \\
& Unimportant & 2 \\
& Quite important & 3 \\
& Important & 4 \\
& Very important & 5 \\
\hline \multirow{3}{*}{ Score of the level of reality } & Answer criteria & Score \\
\cline { 2 - 3 } & Very expensive & 1 \\
& Expensive & 3 \\
& Quite expensive & 4 \\
& Cheap & 5 \\
\hline
\end{tabular}

\section{Result and Discussion}

Travel Cost

Travel cost is the addition of each expenditure which is spent by visitors individually when they visit a tourism place in one trip. Those costs include transportation, consumption, entrance ticket, swimming tire rent, gazebo rent, and so on showed in table 3 .

Table 3. Travel cost of Slanik Waterpark's visitor.

\begin{tabular}{lcrrr}
\hline Clasification & Maximum (Rp) & $\begin{array}{c}\text { Minimum } \\
(\mathbf{R p})\end{array}$ & Average (Rp) & $\begin{array}{c}\text { Average } \\
\text { percentage } \\
(\mathbf{\%})\end{array}$ \\
\hline Transportation & 181,000 & 11,500 & $62,512.93$ & 35.88 \\
Consumption & 80,000 & 20,000 & $46,005.38$ & 26.40 \\
Enterance fee & 50,000 & 35,000 & $42,571.43$ & 24.43 \\
Gazebo rent & 75,000 & 0 & $14,642.86$ & 8.40 \\
Swimming tyre & & 0 & $3,500.00$ & 2.01 \\
rent & 35,000 & 0 & $5,000.00$ & 2.87 \\
Etc. & 35,000 & 66,500 & $174,232.59$ & 100 \\
\hline The total cost & 456,000 & & & \\
\hline
\end{tabular}

Table 3 shows that the accumulation of each cost spent by visitors which can be seen from each cost spent by respondent per individual so that maximum cost, minimum cost, average cost, and average percentage are gained. Minimum cost in the classification of gazebo rent and swimming tire rent value $\mathrm{Rp} 0.00$ because some of visitors uncommonly rent gazebo and swimming tire in their visit. Classification of other costs is $\mathrm{Rp} \mathrm{35,000} \mathrm{since} \mathrm{some} \mathrm{of} \mathrm{visitors}$ spend this cost to pay locker rent or additional hygiene cost for bringing food or snack bought outside of Slanik Waterpark. To count the amount average cost of travel per individual in total trip cost is gained from the addition of costs spent by visitors which cost Rp12,196,21.086. With the number of average cost of Slanik Waterpark visitor per individual per visit which cost Rp174,232.59.

Factor Affecting visitors.

The rapid spread of corona virus affects all aspects in life. This pandemic causes new health protocols implemented in social activities. One of them is tourism activity. That issue affects the number of visit in many tourism places. It 
triggers researchers to test each factor taken into consideration to see the effect of the number of visit which is analyzed by using multiple linear regressions.

Table 4. The Result of Multiple Linear Regression Coefficient Output

\begin{tabular}{|c|c|c|c|}
\hline Model & Coefficient & t-Statistic & Prob \\
\hline (Constant) & 1.2901 & 0.9441 & 0.3488 \\
\hline Travel cost & $-9.6 \mathrm{E}-06 * * *$ & -3.3979 & 0.0012 \\
\hline Distance & 0.0112 & 1.6522 & 0.1036 \\
\hline Hygiene & 0.1650 & 0.8331 & 0.4080 \\
\hline Safety & -0.0372 & -0.2445 & 0.8076 \\
\hline Accessibility & -0.2385 & -0.7704 & 0.4440 \\
\hline Income & $-1.06 \mathrm{E}-07$ & -1.0697 & 0.2889 \\
\hline Facility & 0.2202 & 0.5807 & 0.5636 \\
\hline Visiting days & $-0.7052 * * *$ & -2.8609 & 0.0058 \\
\hline Variable & & & Total \\
\hline R-square & & & 0.2389 \\
\hline Adjusted R-square & & & 0.1391 \\
\hline F-Statistic & & & 2.3938 \\
\hline Prob (F-statistic) $* *$ & & & 0.0257 \\
\hline Durbin Watson & & & 1.9192 \\
\hline The level of c & lence $90 \%$ & & \\
\hline The level of $\mathrm{c}$ & lence $95 \%$ & & \\
\hline The level of $\mathrm{c}$ & lence $99 \%$ & & \\
\hline
\end{tabular}

From the result of regression in the table 4 is gained the multiple linear regression equation below:

$$
\begin{aligned}
\mathrm{Y}= & 1,2901-9,6 \mathrm{E}-06 \mathrm{X}_{1}+0,0112 \mathrm{X}_{2}+ \\
& 0,1650 \mathrm{X}_{3}-0,0372 \mathrm{X}_{4}-0,2385 \mathrm{X}_{5}- \\
& 1,06 \mathrm{E}-07 \mathrm{X}_{6}+0,2202 \mathrm{D}_{1}-0,7052 \mathrm{D}_{2} \\
& +\mathrm{e}
\end{aligned}
$$

Data test had been done before regression of research data was conducted. It is found that there is no multicollinearity and heteroskadesticity in research data. The result of data test in table 4 shows that the factors affecting the number of visit are travel cost and visiting days which are in the level of confidence $99 \%$. This is caused by the fact that the higher travel cost, the lesser visitors will visit. This result is in line with previous research conducted by Arifa (2019) which explains that the higher travel cost, the lesser visitors will visit the tourism place.

On the variable of visiting days, the number of visitors on weekdays is more than the number of visitors on weekends because the situation is not too crowded on weekdays so that it can minimize the spread of Covid 19.

While the variables of distance, safety, hygine, accessibility, income and facilities do not affect tourist visits to the Slanik Waterpark. This is because the majority of visitors are new visitors who first time come to Slanik Waterpark. Then, the perception that Slanik Waterpark is the largest water tourism object in Lampung Province with a strategic location on the Karang Anyar crossing, South Lampung Regency which is connected to Bandar Lampung City, Metro City, South Lampung Regency and East Lampung Regency and good road access plus 
the presence of toll roads attract people to visit Slanik Waterpark.

\section{Economic Value Based On Travel Cost}

The travel cost approach can be used as an estimation step to determine the economic value of tourist attraction recreational services. This method was chosen based on the advantages of obtaining real data from the cost of visits made by a person on a tour. The calculation of the economic value of the Slanik Waterpark tourist attraction uses data on the number of visitors in 2017 of 118,116 people in one year.

Travel cost coefficients that have been analyzed by using multiple linear regression tests can be used as a calculation of the economic value of the Slanik Waterpark. Travel costs that have been analyzed using multiple linear regression can be used. The calculation of the economic value of the Slanik Waterpark tourist attraction can be seen in table.

Table 5. The economic value of Slanik Waterpark

\begin{tabular}{lr}
\hline \multicolumn{1}{c}{ Explanation } & \multicolumn{1}{c}{ Value } \\
\hline The number of respondent (person) (a) & 70 \\
The number of visit per year (Times peryear) (b) & 118,116 \\
Coefficient travel cost (c) & 0.00000969 \\
Consumer surplus (Rp) (d) & $22,291,022$ \\
Consumer surplus / individual/ visit (Rp) (e) & 110,571 \\
The total of economic value (Rp) ( b x e ) & $13,060,150,376$ \\
\hline
\end{tabular}

Table 5 shows the consumer surplus of each individual per visit at Slanik Waterpark is IDR $22,291,022$ so that the results of the economic value at the Slanik Waterpark tourist attraction are IDR 13,060,150,376 in a year. This value is quite high compared to the Dayu Park water tourism park in Sragen, Central Java Province with an economic value of IDR 260,841,380 (Ermayanti, 2012). This shows the attractiveness of the Slanik Waterpark has a fairly high economic value for existing resources. Thus, the tourism services provided by Slanik Waterpak can provide benefits and need to be maintained.

Visitor Satisfaction Based on Level of Importance with Reality

Customer or visitor satisfaction is a feeling or a form of someone's disappointment caused by having a desire to judge by comparing a performance that handles a product (or result) towards consumer expectations (Kotler and Keller, 2008). The costs spent by visitors when they travel to Slanik Waterpark have different levels of importance for each visitor. To determine this importance, the customer satisfaction index (CSI) is used on the cost attributes spent by each visitor by first knowing average importance score (RSP), average reality score (SSR), weighting factor (WF) and weighting score (WS).The Likert scale is used to see the level of importance and the reality that exists which is used as a measuring tool to see the value of importance for the costs spent by visitors when they travel (very important, important, quite important, not important and very unimportant) then to see the level of reality which is seen as very expensive, expensive, quite expensive, cheap and very cheap. It is used as a reference in measuring the satisfaction of visitors to the Slanik Waterpark in traveling. 
Table 6. Interest level index calculation and reality

\begin{tabular}{llcccc}
\hline No & \multicolumn{1}{c}{ Attribute } & Percentage & $\begin{array}{c}\text { Importance Level } \\
\text { Index }\end{array}$ & Percentage & $\begin{array}{c}\text { Reality } \\
\text { Index }\end{array}$ \\
\hline 1 & $\begin{array}{l}\text { The total of } \\
\text { travel cost }\end{array}$ & 68.86 & Important & 67.14 & Cheap \\
2 & $\begin{array}{l}\text { Transportation } \\
\text { cost }\end{array}$ & 56.57 & Quite important & 68.86 & Cheap \\
3 & $\begin{array}{l}\text { Consumption } \\
\text { cost }\end{array}$ & 74.00 & Important & 72.57 & Cheap \\
4 & Enterance ticket & 67.14 & Important & 64.29 & Cheap \\
5 & fee & 64.57 & Important & 55.43 & Quite cheap \\
6 & $\begin{array}{l}\text { Gzebo rent cost } \\
\text { Swimming tyre }\end{array}$ & 59.71 & Quite important & 61.43 & Cheap \\
7 & $\begin{array}{l}\text { rent cost } \\
\text { Cable car cost }\end{array}$ & 69.71 & Important & 68.86 & Cheap \\
8 & $\begin{array}{l}\text { Parking fee } \\
9\end{array}$ & 67.14 & Important & 72.57 & Cheap \\
Others. & 87.71 & Very important & 69.43 & Cheap \\
\hline
\end{tabular}

Table 6 shows the calculation of importance level index of each cost model which is used as an attribute in determining the level of visitor satisfaction in Slanik Waterpark. The lowest percentage value in the importance level is transportation cost, but in the reality, transportation cost is valued cheap with the percentage $68.86 \%$. This shows the importance level will not be always the same as what the visitors feel towards the costs spent when the visitors visit Slanik Waterpark.

Table 7. Calculation and interpretation of satisfaction level with CSI analysis

\begin{tabular}{clcccc}
\hline No & \multicolumn{1}{c}{ Attribute } & RSP & WF & RSK & WS \\
\hline 1 & The total of travel cost & 3.44 & 0.11 & 3.36 & 0,38 \\
2 & Transportation cost & 2.83 & 0.09 & 3.44 & 0,32 \\
3 & Consumption cost & 3.70 & 0.12 & 3.63 & 0,44 \\
4 & Enterance ticket fee & 3.36 & 0.11 & 3.21 & 0,35 \\
5 & Gazebo rent cost & 3.23 & 0.10 & 2.77 & 0,29 \\
6 & Swimming tyre rent cost & 2.99 & 0.10 & 3.07 & 0,30 \\
7 & Cable car cost & 3.49 & 0.11 & 3.44 & 0,39 \\
8 & Parking fee & 3.36 & 0.11 & 3.63 & 0,40 \\
9 & Others & 4.39 & 0.14 & 3.47 & 0,49 \\
\hline The total number & 30.77 & 1.00 & 30.03 & 3.35 \\
\hline CSI & & & & 66.97 \\
\hline
\end{tabular}


Table 7 shows that Slanik Waterpark Visitor Satisfaction in the importance level and the reality of costs spent in visiting Slanik Waterpark is satisfied, because according to the resulting scale of the calculation of the CSI analysis resulted in the number 66.97. This satisfaction occurs because every visitor who comes to the Slanik Waterpark is quite loyal to consider the costs spent in traveling because most visitors coming from some regions think that every nominal money spent in visiting and seeing the condition of the existing Slanik Waterpark tourist attraction is very worth it. This result is in line with Amaliawati's research in (2015) that in her research on the satisfaction level of visitors to the Umbul Penging tourist attraction, one of the cost factors which spend in traveling such as ticket have a positive effect on consumer satisfaction.

\section{Conclusion}

The average travel cost spent by visitors per individual per visit is IDR 174,232.59 with higher expenditure allocation spent is transportation cost worth IDR 62,512.93 per individual. Factors affecting the number of visit in Slanik Waterpark are travel cost and visiting days on weekdays there are more than 45 people compared to visitors on weekends as many as 25 people. Economic value in Slanik Waterpark which is resulted by using travel cost method is IDR 13,060,150,376 per year. Most of visitors are satisfied with each attribute cost they spend when they visit Slanik Waterpark.

\section{References}

Amaliawati, S. 2015. Pengaruh Fasilitas dan Harga Tiket Terhadap Kepuasan Pengunjung Obyek Wisata Umbul Penging. Skripsi. Universitas Muhammadiyah Surakarta. Surakarta.

Arifa, E. 2019. Valuasi Ekonomi Kawasan Wisata Pulau Pisang Kabupaten Pesisir
Barat. Skripsi. Fakultas Pertanian Universitas Lampung. Lampung.

Dwiatmojo, A. (2015). Valuasi Nilai Ekonomi Wisata Pantai Amal: Aplikasi TravelCost Method (TCM).

Researchgate,https://www.researchgate.net /publicatio n/305778000, diakses Agustus 2019.

Ermayanti, F. 2012. Valuasi Ekonomi Objek Wisata Ndayu Paark Dengan Metode Biaya Perjalanan dan Metode Valuasi Kontingensi. Universitas Sebelas Maret. Solo. https://digilib.uns.ac.id. Diakses pada Tanggal 14 September 2020

Fauzi, A. 2006. Ekonomi Sumber Daya Alam dan Lingkungan. Gramedia Pustaka Utama. Jakarta

Fauzi, A. 2014. Valuasi Ekonomi dan Penilaian Kerusakan Sumber Daya Alam dan Lingkungan. PT Penerbit IPB Press. Jakarta

Ghozali I. 2011. Aplikasi Analisis Multivariate dengan Program SPSS. Edisi Ke-4. Universitas Diponegoro. Semarang.

Kotler, P. dan K. L. Keller. 2008. Manajemen Pemasaran, Jilid 1. Penerbit Erlangga. Jakarta.

Marsinko A, WT Zawacki., dan JM Bowker. 2002. Use travel cost model in planning: a case study. Tourism analysis. 6(1):203-

211.https://www.researchgate.net/publicat ion/233675295_Use_of_Travel_C ost_Models_in_Planning_A_Case_Study/ download. Diakses pada tanggal 23 Juli 2019.

Nugroho, P. S. 2010. Valuasi Ekonomi Wisata Pantai Glagah Dengan Pendekatan 
Biaya Perjalanan (Travel Cost) di Desa Glagah Kecamatan Temon Kabupaten

Kulon Progo. Skripsi. Universitas Sebelas Maret.

Supranto, J. 2006. Pengukuran Tingkat Kepuasan Pelanggan Untuk Menaikkan
Pangsa Pasar, Cetakan keempat. PT Rineka Cipta. Jakarta.

UU No. 9 Tahun 1990. Kepariwisataan.http:// www. kemenpar. go. id/userfiles /file/4636_1364UUTentangKepariwisataa nnet1.pdf. Diakses pada 10 November 2019 